\title{
Does the presence of livestock alter the trophic behaviour of sympatric populations of wild camelids Vicugna vicugna Molina 1782 and Lama guanicoe Müller 1976 (Artiodactyla: Camelidae)? Evidence from Central Andes
}

\author{
¿La presencia de ganado domesticado altera la conducta trófica de poblaciones \\ simpátricas de los camélidos silvestres Vicugna vicugna Molina 1782 y Lama guanicoe \\ Müller 1976 (Artiodactyla: Camelidae)? Evidencia de los Andes Centrales
}

\author{
Carlos Tirado ${ }^{1 *}$, A. Cortés ${ }^{2}$, M. A. Carretero ${ }^{3} \&$ Francisco Bozinovic $^{4}$ \\ 1'Departamento de Química y Biología, Facultad de Ciencias Naturales, Universidad de Atacama, Casilla 576, Copiapó, Chile \\ 2Departamento de Biología, Facultad de Ciencias, Universidad La Serena, Casilla 599, La Serena, Chile \\ ${ }^{3} \mathrm{CIBIO}$ Research Centre in Biodiversity and Genetic Resources, InBIO, Universidade do Porto, Campus Agrário de Vairão, \\ Rua Padre Armando Quintas, No 7. 4485-661 Vairão, Vila do Conde, Portugal ${ }^{d}$ \\ ${ }^{4}$ Departamento de Ecología and Center of Applied Ecology \& Sustainability (CAPES), Facultad de Ciencias Biológicas, \\ Pontificia Universidad Católica de Chile, Santiago 6513677, Chile \\ *E-mail: carlos.tirado@uda.cl (C. Tirado).
}

\begin{abstract}
We described and compared the diets of two sympatric Andean camelids, during the humid season (austral summer) in a site of Northern Chile, in presence of domestic livestock. Results indicate that: 1) grasses and shrubs are the main component in the diet of both camelids, 2) shrubs were more consumed by V. vicugna; 3) V. vicugna and L. guanicoe used the same trophic resources but in different proportions; 4) in mountain environments, wetlands exploitation by wild camelids seems restricted by domestic cattle, which would cause the displacement of Vicuñas and Guanacos to suboptimal habitat for feeding.
\end{abstract}

KEYwords: Guanaco, Vicuña, livestock, diet, herbivory.

\begin{abstract}
RESUMEN
Describimos y comparamos la dieta de dos poblaciones simpátricas de camélidos silvestres, durante la estación húmeda (verano) en un sector del norte de Chile en presencia de ganado domesticado. Nuestros resultados indican que: 1) gramíneas y arbustos son el principal componente de la dieta de ambos camélidos; 2) arbustos fueron consumidos principalmente por V. vicugna; 3) V. vicugna and L. guanicoe utilizan los mismos recursos tróficos pero en diferentes proporciones; 4) en ambientes de montaña, el uso de vegas altoandinas por parte de camélidos silvestres estaría siendo restringido por la presencia de ganado domesticado, el cual provocaría el desplazamiento de ambos camélidos a zonas subóptimas de alimentación.
\end{abstract}

Palabras claves: Guanaco, Vicuña, ganado, dieta, herbivoría.

\section{INTRODUCTION}

In places where vegetation has developed adaptations to cope with herbivores (Granados-Sánchez et al. 2008), herbivorous mammals must have strategies for obtaining, processing, and using food. A clear example of this is the high Andean environment, where food is not only scarce, but highly variable in time and space (Baied \& Wheeler 1993). Under these conditions, resources are distributed in two main areas: steppe, where vegetation is mostly grasses and resinous shrubs; and wetlands, where grasses and pseudograsses, with a relatively constant water supply, prevail (Villagrán et al. 1983). Wetlands play an important role because they harbor an important biodiversity (Squeo 
et al. 2006a), constituting in some cases critical habitat for wild vertebrates, such as the case of South American camelids (Wurstten et al. 2014).

The presence of herbivorous mammalian species, which are able to take advantage of this type of greatly restrictive environment, sets up the perfect scenario to evaluate their mechanisms involved in using and processing food resources. In these environments, interspecific competition may be reduced through niche segregation (Jaksic \& Marone 2007), hence, closely related species can coexist in sympatry. Alternatively, it may lead to suboptimal use of resources by one of the competitors, condition that has been documented for wild camels that coexist in sympatry with exotic species (Borgnia et al. 2008).

Wild South American camelids represent one of the main groups of vertebrates which have been able to take advantage of this type of environment (Franklin 1982). Vicugna vicugna and Lama guanicoe are two wild camelids currently inhabiting arid and semiarid environments of South America. Although both species differ in their distribution patterns (altitudinal and latitudinal), they may live sympatrically in highlands (Franklin 1982). Such is the case with the camelids populations of the high Andean area of the north of Chile, specifically "El Morro" (28 37'46"S 69 56'13'W, Alto del Carmen, Región de Atacama), which is also used as summer meadows (summer cattle) to feed livestock.

The aim of this work is to describe and compare the diets of two sympatric Andean camelids, during the humid season in a site of Northern Chile, in presence of domestic livestock. It is worth mentioning that studies about the ecology of sympatric populations of wild camelids are not only scarce (Lucherini 1996, Lucherini \& Birochio, 1997, Wurstten et al. 2014) but also essential for their conservation and management.

Consequently, the hypotheses we tested were: 1) if both camelids live in sympatry with livestock, taking advantage of areas where resources vary on their quantity and quality (reduced palatability), we would expect a significant segregation of both camelids' trophic niche; 2) due to the presence of domesticated cattle, wild camels would reduce the use of wetlands as feeding areas, favoring the use of steppe areas.

In order to test these hypotheses, trophic ecology was evaluated based on the availability of food, chemical composition of food items, trophic resources, trophic selection, and trophic overlap of the sympatric populations of $V$. vicugna and L. guanicoe, in presence of cattle.

\section{MATERIALS AND METHOD}

STUDy AREA

This study was carried out during summer (February 2010) in "El Morro" (28 $37^{\prime} 46^{\prime}$ "S - 69 $9^{\circ} 56^{\prime} 13^{\prime}$ 'W, altitudinal range: from 3500 to 4300 m.a.s.l., Alto del Carmen, Región de Atacama), in an area of 8235 ha. The climate is arid, with a mean temperature of $3^{\circ} \mathrm{C}$ (maximum temperature $=14^{\circ} \mathrm{C}$, and minimum $=-6.4^{\circ} \mathrm{C}$ ), and an average annual precipitation of $214 \mathrm{~mm}$, which is mainly concentrated as snow between June and November (Knight Piésold S. A. 2008). The two prevailing types of vegetation are evergreen herbs, mainly located in azonal vegetation areas (wetlands or Andean meadows), and shrubby vegetation distributed in areas of zonal vegetation (slopes). El Morro is used as summer pastures to feed domestic livestock, which principally includes horses and goats. During the study period, 299 animals belonging to the species Capra hircus (Goat, n= 267), Equus caballus (Horse, $\mathrm{n}=27$ ) and E. asinus (Donkey, $\mathrm{n}=3$ ) were detected.

\section{STUDY SPECIES}

$V$. vicugna has an average body mass of $35 \mathrm{~kg}$. This species is distributed just in Andean and high plateau areas (3000 - 4600 m.a.s.1.) (Franklin 2011). In Chile, it is considered an endangered species (SAG 2012). Studies of the trophic ecology of $V$. vicugna are scarce in Chile (Tirado et al.2012), although there is comparative information on this topic for populations from other countries (Cajal 1989, Aguilar et al. 1995, Borgnia et al. 2008, Cassini et al. 2009). V. vicugna has been considered a strict grazer (Ménard 1984, Aguilar et al. 1999), whereas other studies also report their consumption of shrubs (Aguilar et al. 1995, Cajal 1989, Borgnia et al. 2008, Borgnia et al. 2010, Tirado et al. 2012). On the other hand, L. guanicoe has a larger body mass (90 - 140 $\mathrm{kg}$ ). Populations of this species occupy a wide altitudinal distribution (0 - 4350 m.a.s.l.), being either sedentary or migratory (Franklin 1982, Contreras et al. 2006). In the North of Chile, L. guanicoe is considered locally as Endangered Species (SAG 2012). As for this species diet, in high Andean areas with wetlands L. guanicoe has been reported to eat mainly grasses and pseudograsses, whereas in wetlands absence its diet consists mainly on grasses, and secondarily shrubs (Cortés et al. 2003, Puig et al. 2011).

\section{FoOD RESOURCE AVAILABILITY}

Vegetation cover (\%) was obtained by the point quadrat method (Mueller-Dombois \& Ellerberg 1974). A total of 40 transects of 50 meters long were performed in areas where camelids frequently foraged, and/or where the presence of fresh feces were detected (community dung piles). Each transect was divided into 50 points, and separated each 100 $\mathrm{cm}$. The foliage cover of plant species was determined by the sum of all transects, with a total of 2000 points sampled. 


\section{REFERENCE SAMPLING}

Leaves, flowers, and stalks of plant species detected in the study area (Table 1) were collected during summer time, which were identified in the herbarium of Universidad de La Serena. The epidermal tissues were used to prepare the microhistological reference sampling (Williams 1962).

FECES SAMPLING AND HISTOLOGICAL PREPARATIONS

10 samples of $V$. vicugna and 10 samples of L. guanicoe fresh feces were collected in areas where individuals were foraging. Each sample was made up of 10 feces samples from adult individuals, which were randomly picked from community dung piles. To obtain fecal samples from each species, we observed both camelids with binoculars, and collected the pellets just after vicuñas and guanacos defecated in the dung piles.

Samples were dried out and kept at $60^{\circ} \mathrm{C}$. From a feces pool made from each sample, a microhistological preparation was composed through Williams's technique (Williams 1962, Dizeo de Strittmatter 1984). This method was repeated for each of the samples collected, obtaining a total of 10 preparations per species (Cortés et al. 2003, Cortés et al. 2006, Tirado et al. 2012).

\section{DiET ASSESSMENT}

A total of 20 microscopic fields randomly picked from each of the histological preparations were analyzed. In total, 200 microscopic fields were observed (20 fields x 10 preparations) for each species. To avoid analyzing a field more than once, the coordinates of each field were recorded. Observations were carried out with a Nikon ${ }^{\circledR}$ (Eclipse E-200) with a reticulate lens of $20 \times 20$ quadrants with a magnification of $40 \mathrm{X}$. Fields with less than $50 \%$ of the area used were excluded (Cortés et al. 2003, Cortés et al. 2006). Epidermic material was identified at species level using the reference collection. Diet composition was estimated as the relative area occupied by each plant species, which allowed calculating the frequency of the consumed items. Fiber content and non-identified material was displayed in percentage.

Chemical analysis of Vegetal samples

During the measuring of vegetal cover, samples of identified species were collected; 50 grams (dry weight) of each of the species included in the diet were chemically analyzed according to A.O.A.C (1970). The determined parameters were raw protein $(\mathrm{g} / 100 \mathrm{~g})$ and raw fiber $(\mathrm{g} / 100 \mathrm{~g})$.

\section{STATISTICAL ANALYSIS}

Trophic diversity was calculated through the ShannonWiener's diversity index (Shannon 1948): $H^{\prime}=-\Sigma p_{i} \mathrm{x} \ln p_{i}$ where $p_{i}=n_{i} / N$, is the proportion of a certain plant species being $n_{i}=$ number of items of the species $\mathrm{i}$ in the diet and $N$
$=$ total number of items in the diet. To assess trophic overlap, Schoener's Index (1968) was used: PS $=1-1 / 2 \sum \mid$ pi - qi $\mid$, where: $P S=$ Schoener overlap index for species $\mathrm{p}$ and $\mathrm{q}$, $\mathrm{p}_{i}=$ proportion of item $i$ in species $\mathrm{p}$ diet, $\mathrm{q}_{i}=$ proportion of $i$ in species q diet. A higher value than 0.6 or $60 \%$ of this index is considered of biological importance (Mathur 1977). To obtain parametric estimators of the means and to estimate confidence intervals of the diversity indexes and overlap, the jackknife technique was used (Jaksic \& Medel 1987). The interspecific comparison of Shannon-Wiener's diversity index and fiber content were compared with the Student $\mathrm{t}$ test, using a value of $\mathrm{p}<0.05$.

The proportions of resources used and available were compared applying log-likelihood ratio test $\left(\mathrm{X}_{\mathrm{L}}{ }^{2}\right)$, proposed by Manly et al. (2002). As this test does not provide statistical differences among proportions, Manly's selection coefficient $\left(\mathrm{w}_{\mathrm{i}}\right)$ was calculated (Manly et al. 2002). To validate statistically that index, a confidence interval on $\mathrm{w}_{i}$ was estimated, using the Bonferroni inequality modified by Manly et al. (2002). It was considered a positive selection or "preferred" if the inferior limit of the interval is superior to 1 , whereas if the superior limit of the interval is less than 1 , it was considered a negative selection or "avoided". Intervals including 1 were considered as random consumption. For calculating resources selection, the adehabitat package (Calenge 2006) for R (R Development Core Team 2008) was used.

\section{RESULTS}

\section{Absolute Plant COVER}

A total of 30 plant species from 16 different families were identified from the study area. The vegetation cover was equivalent to $47.01 \%$, whereas the bare soil represented $52.99 \%$ (Table 1). Of the 30 species mentioned, 13 were found in zonal vegetation areas and 17 in azonal vegetation areas.

Relative Plant COVER (POTENTIAL AVAILABILITy OF FOOD RESOURCE)

The most abundant ones were pseudograsses Carex gayana, grasses Deyeuxia velutina, and shrub Adesmia hystrix which covered 20.62, 19.94 and $6.26 \%$ respectively (Table 1).

\section{DiET COMPOSITION}

Both camelids consumed $37 \%$ of the available resources, including each of them, 10 items (Table 2). Botanical composition of $V$. vicugna's diet consisted mainly of grasses $(40.10 \%)$ and shrubs $(33.86 \%)$, and, to a lesser extent, of pseudograsses $(7.17 \%)$ and herbs $(0.06 \%)$. The most representative species in the grasses group were Jarava frigida and D. velutina, which were consumed at 
$16.90 \%$, and $16.00 \%$. The shrubs in the diet consisted of just two species, A. subterranea (30.34\%) being the most abundant. The group of pseudograsses was represented by four species; the most consumed was C. gayana $(5.46 \%)$. In contrast to $V$. vicugna, L. guanicoe presented a higher intake of grasses up to $64.44 \%$, whereas bushy plants and pseudograsses intake were just $7.27 \%$ and $6.70 \%$, respectively. From the group of grasses, L. guanicoe mainly consumed $J$. frigida (40.81\%) and Deschampsia caespitosa $(22.80 \%)$. On the other hand, L. guanicoe's diet included less proportion of shrubs such as A. subterranea (4.64\%). The most consumed pseudograsses were C. gayana $(3.48 \%)$ (Table 2). By clustering the relative consumption of vegetal species according to the type of vegetation (zonal - azonal), it was found out that the main item in both species diet was zonal vegetation ( $V$. vicugna: $50.82 \%$ and $L$. guanicoe: $48.08 \%$ ). Species richness was similar (Table 2). Regarding fiber content of feces, it was $17.60 \%$ for $V$. vicugna and $20.31 \%$ for $L$. guanicoe, but both values were statistically different (t: 15 , df: $18 ; \mathrm{p}<0.0001)$.

TROPHIC DIVERSITY AND DIET OVERLAP

Trophic diversity, estimated through the Shannon Wiener's index $\left(\mathrm{H}^{\prime}\right)$, was 1.66 for $V$. vicugna and 1.54 for $L$. guanicoe, values which differed statistically (t: 8.34 ; df: 10986; $\mathrm{p}<0.0001$ ) (Table 2). Trophic overlap, determined by Schoener's index (PS), was 38\% (Table 2).
TROPHIC SELECTION

Comparing the proportion of items in the diet (excluding unknown material and fiber) with the expected values of consumption estimated from plant cover, significant differences were found in both camelids ( $V$. vicugna: $\mathrm{X}_{\mathrm{L}}^{2}$ : 46024; df: 9; $<0.0001$ L. guanicoe: $\mathrm{X}_{\mathrm{L}}^{2}$ : 48965; df: 9; $\mathrm{p}$ $<0.0001$ ), indicating that certain plant species were either preferred or avoided (Table 3 ). Of the 10 species consumed by $V$. vicugna, just four were preferred. Among them, the bushy plants $A$. subterranea and $J$. uniflora were highly selected, while Festuca wernermannii and J. frigida were preferred to a lesser extent. The other species consumed were avoided (Table 3). Similar to V. vicugna, L. guanicoe preferred four of the 10 items included in its diet, showing strong preference towards $J$. frigida, D. caespitosa, Junellia uniflora and A. subterranea, while the other species were avoided (Table 3 ). When assessing the selection considering functional groups only, both camelids showed preference towards shrubs and grasses (Table 4).

\section{ChemiCAL PROPERTIES OF PREFERRED ITEMS}

Chemical analyses (g/ 100g) indicated that plant species selected by vicuñas and guanacos showed average nitrogen content of $5.4 \pm 2.1 \mathrm{~g} / 100 \mathrm{~g}$. Shrub species A. subterranea had the highest value $(7.7 \mathrm{~g} / 100 \mathrm{~g})$. As for fiber, selected species had an average value of $24.8 \pm 8.8 \mathrm{~g} / 100 \mathrm{~g}$, and shrub species $A$. subterranea had the lowest value (14.6 g / 100g).

TABLE 1. Vegetal species in the study area. For each of them, tables indicate functional group, family, distribution $($ zonal $=\mathrm{Z}$ or azonal $=$ A), absolute and relative cover.

Tabla 1. Especies vegetales en el área de estudio. Para cada una de ellas se indica grupo funcional, familia y distribución (zonal= Z o azonal $=\mathrm{A}$ ), cobertura absoluta y relativa.

\begin{tabular}{|c|c|c|c|}
\hline \multirow{2}{*}{$\begin{array}{l}\text { FUNCTIONAL GROUP } \\
\text { FAMILY } \\
\text { Species }\end{array}$} & \multirow[t]{2}{*}{ Distribution } & \multicolumn{2}{|c|}{ Cover $(\%)$} \\
\hline & & Absolute & Relative \\
\hline \multicolumn{4}{|l|}{ SHURBS } \\
\hline \multicolumn{4}{|l|}{ FABACEAE } \\
\hline Adesmia echinus & Z & 0.18 & 0.39 \\
\hline Adesmia hystrix & Z & 2.94 & 6.26 \\
\hline Adesmia subterranea & Z & 0.63 & 1.35 \\
\hline \multicolumn{4}{|l|}{ SOLANACEAE } \\
\hline Fabiana imbricata & Z & 0.72 & 1.54 \\
\hline \multicolumn{4}{|l|}{ VERBENACEAE } \\
\hline Junellia uniflora & Z & 0.18 & 0.39 \\
\hline \multicolumn{4}{|l|}{ UMBELLIFERAE } \\
\hline Azorella compacta & Z & 0.18 & 0.39 \\
\hline Azorella madreporica & Z & 0.54 & 1.16 \\
\hline Subtotal (\%) & & 5.39 & 11.46 \\
\hline HERBACEOUS & & & \\
\hline
\end{tabular}




\begin{tabular}{|c|c|c|c|}
\hline \multirow{2}{*}{$\begin{array}{l}\text { FUNCTIONAL GROUP } \\
\text { FAMILY } \\
\text { Species }\end{array}$} & \multirow[t]{2}{*}{ Distribution } & \multicolumn{2}{|c|}{ Cover $(\%)$} \\
\hline & & Absolute & Relative \\
\hline \multicolumn{4}{|l|}{ CAMPANULACEAE } \\
\hline Lobelia oligophylla & A & 0.18 & 0.39 \\
\hline \multicolumn{4}{|l|}{ CRUCIFERAE } \\
\hline Descurainia pimpinellifolia & Z & 0.23 & 0.48 \\
\hline \multicolumn{4}{|l|}{ FABACEAE } \\
\hline Astragalus bustillosii & A & 0.18 & 0.39 \\
\hline \multicolumn{4}{|l|}{ HALORAGACEAE } \\
\hline Myriophyllum quitense & A & 0.09 & 0.19 \\
\hline \multicolumn{4}{|l|}{ MALVACEAE } \\
\hline Cristaria andicola & $\mathrm{Z}$ & 1.81 & 3.85 \\
\hline \multicolumn{4}{|l|}{ PLANTAGINACEAE } \\
\hline Plantago barbata & A & 0.68 & 1.45 \\
\hline \multicolumn{4}{|l|}{ PORTULACEAE } \\
\hline Lenzia chamaepitys & $\mathrm{Z}$ & 0.54 & 1.16 \\
\hline \multicolumn{4}{|l|}{ RANUNCULACEAE } \\
\hline Ranunculus cymbalaria & A & 0.91 & 1.93 \\
\hline \multicolumn{4}{|l|}{ URTICACEAE } \\
\hline Urtica mollis & $\mathrm{Z}$ & 0.18 & 0.39 \\
\hline Subtotal (\%) & & 4.80 & 10.21 \\
\hline \multicolumn{4}{|l|}{ GRASSES } \\
\hline \multicolumn{4}{|l|}{ POACEAE } \\
\hline Deschampsia caespitosa & A & 1.63 & 3.47 \\
\hline Deyeuxia velutina & A & 9.38 & 19.94 \\
\hline Festuca rubra & A & 0.50 & 1.06 \\
\hline Festuca werdermannii & A & 0.50 & 1.06 \\
\hline Hordeum comosum & $\mathrm{Z}$ & 0.09 & 0.19 \\
\hline Jarava frigida & $\mathrm{Z}$ & 2.13 & 4.53 \\
\hline Poa pratensi & A & 0.27 & 0.58 \\
\hline Puccinellia frigida & A & 0.50 & 1.06 \\
\hline Sub total $(\%)$ & & 14.99 & 31.89 \\
\hline \multicolumn{4}{|l|}{ PSEUDOGRASSES } \\
\hline \multicolumn{4}{|l|}{ CYPERACEAE } \\
\hline Carex gayana & A & 9.69 & 20.62 \\
\hline Eleocharis albibracteata & A & 1.18 & 2.50 \\
\hline Phylloscirpus deserticota & A & 4.30 & 9.15 \\
\hline \multicolumn{4}{|l|}{ JUNCACEAE } \\
\hline Juncus arcticus & A & 2.13 & 4.53 \\
\hline Juncus bufonius & A & 0.59 & 1.25 \\
\hline Oxychloe andina & A & 3.94 & 8.38 \\
\hline Subtotal (\%) & & 21.83 & 46.44 \\
\hline Vegetal cover & & 47.01 & 100.00 \\
\hline Bare soil & & 52.99 & - \\
\hline Total & & 100.00 & 100.00 \\
\hline Species Richness & & & \\
\hline
\end{tabular}




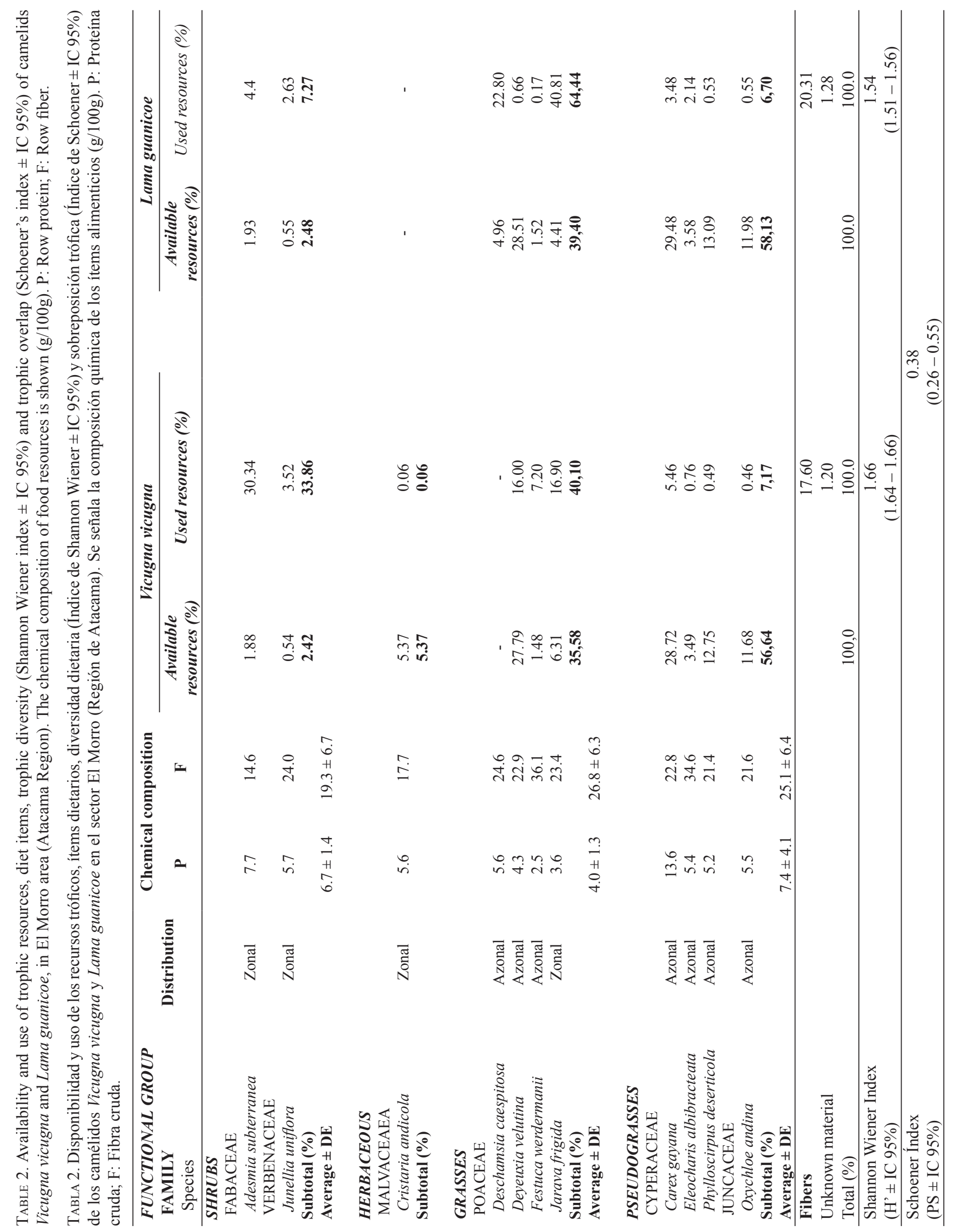


Trophic behaviour of sympatric populations of wild camelids Vicugna vicugna and Lama guanicoe: CARLOS TIRADO ET AL.

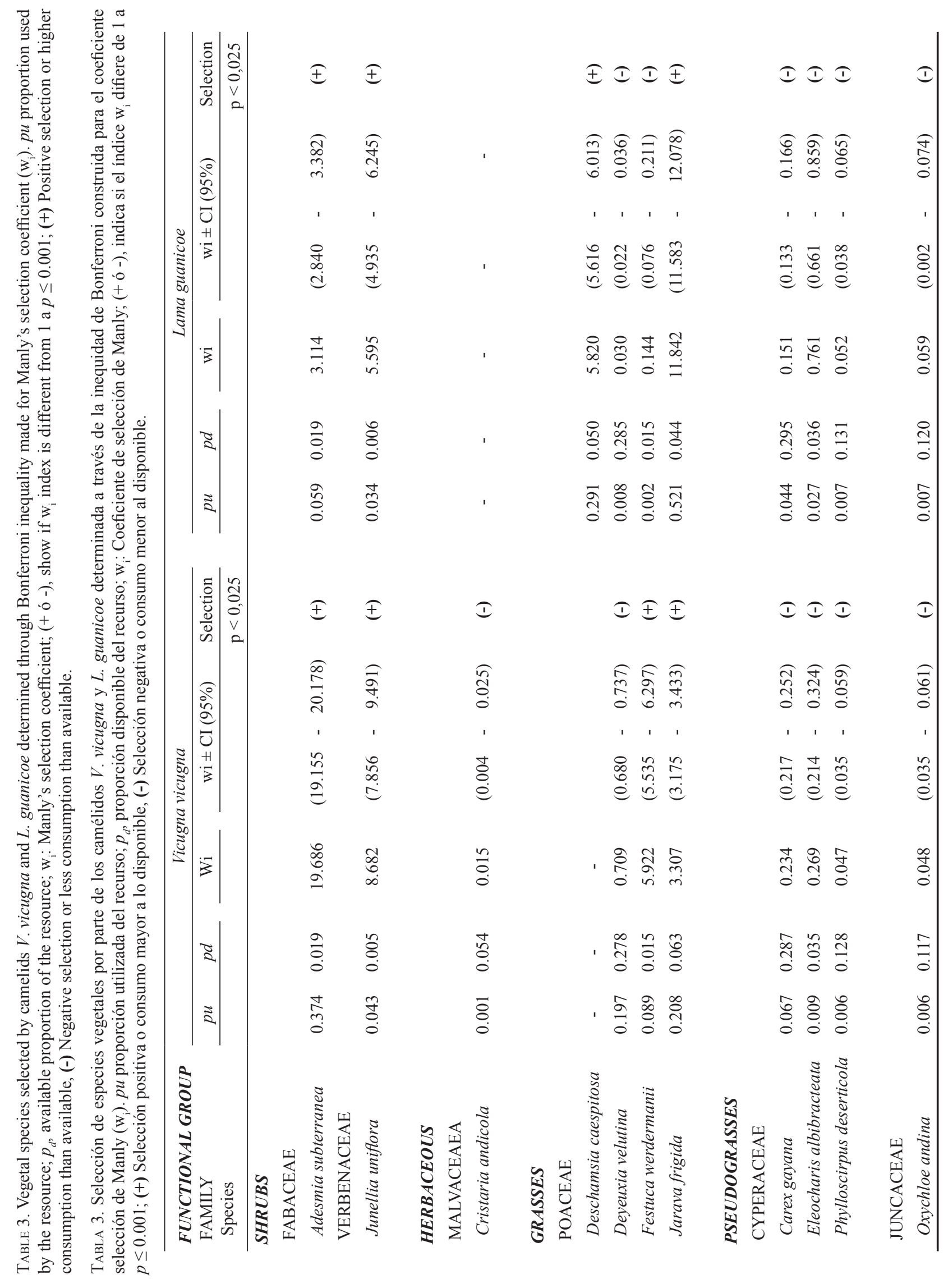




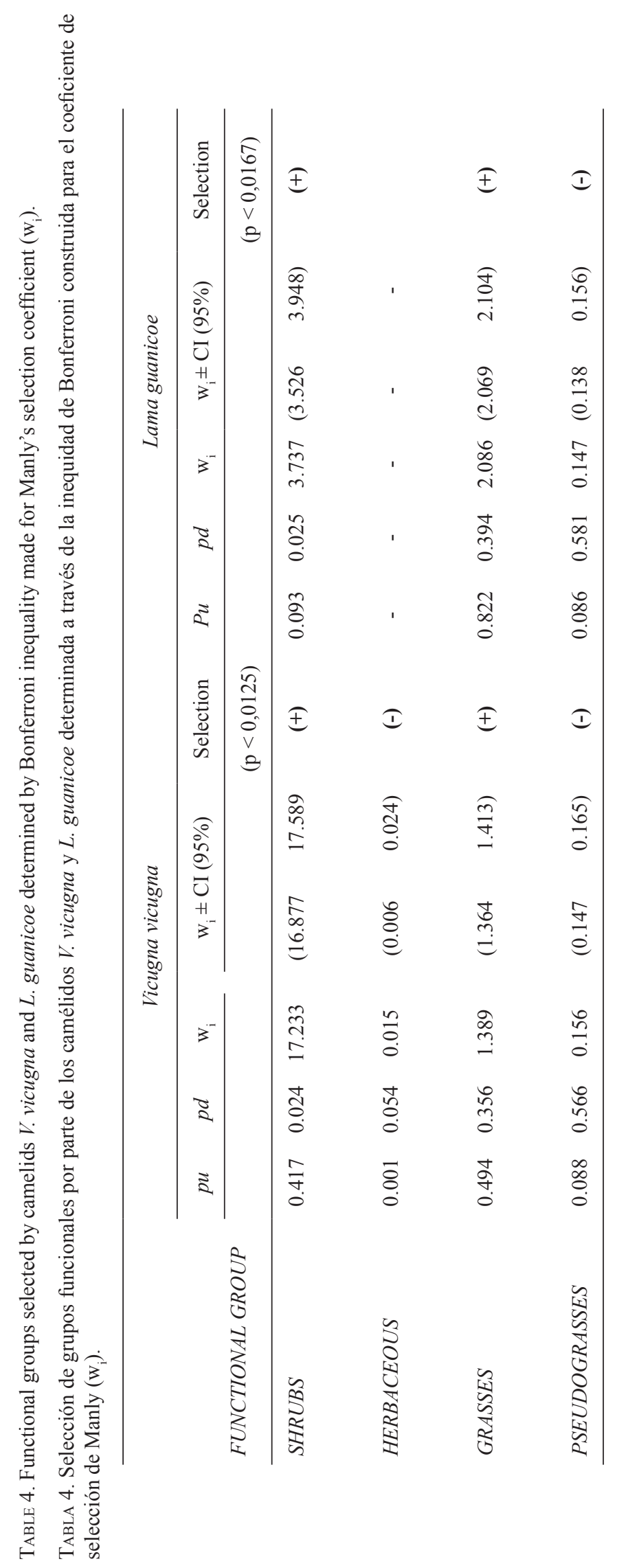




\section{DISCUSSION}

AvaILABILITY AND QUALITY OF FOOD RESOURCES

The potential resource availability consisted of 30 plant species distributed among zonal (43\%) and azonal (57\%) vegetation areas. Of those identified during summer in the study zone, both camelids consumed only 10, distributed among groups of typical plants from Andean grasslands (grasses, pseudograsses, shrubs, and herbs). These groups also contained different proportions of protein and fiber. These last variables may not be the best parameter, but which allows characterizing, in a general way, the nutritional quality of forage. Shrubs and herbaceous species showed fiber content ranging between $14 \%$ and $24 \%$, whereas grasses and pseudograsses were characterized by fiber content values ranging between $21 \%$ and $36 \%$. As for the protein content, functional groups with higher percentage were shrubs (6.7\%) and pseudograsses (7.4\%). Among the highest values, Adesmia subterranea, species belonging to the family Fabaceae, is characterized by its nitrogen fixing ability (Squeo et al. 2006b).

\section{BOTANICAL COMPOSITION OF THE DIET}

As reported for other areas (Cortés et al. 2006, Cassini et al. 2009, Puig et al. 2011, Tirado et al. 2012), grasses were the main component of $V$. vicugna and L. guanicoe diet, which were also preferred. The fact that both species consumed high amount of grasses is clearly associated with the different adaptations for digesting fiber of camelids such as: 1) stomach compartments, which allow them to increase fermentation, water and salts absorption (San Martín 1987), 2) their long times of retention compared to other artiodactyls (Sponheimer et al. 2003), 3) their ability to reduce urea excretion at a renal level (Engelhardt \& Holler 1982). Even though both camelids shared this pattern, grasses intake was 1.6 times higher in L. guanicoe than in $V$. vicugna. In fact, being bigger $L$. guanicoe also had larger stomach compartments, which likely had a significant effect on retention times that tend to be 1.2 times higher for this species compared to $V$. vicugna (San Martín 1987). Although shrubs have been characterized by their high protein content and low cell walls components content (Borgnia et al. 2010), they were represented by only two species in the diet of both camelids. Nevertheless, they constituted the second most representative group in $V$. vicugna and L. guanicoe diet. Even though this functional group was preferred by both species, $V$. vicugna showed a 4.6 times higher value of consumption and selection. This has to be interpreted in the light of the high intake of the nitrogen- fixing $A$. subterranea, which was characterized by its higher content of raw protein. It is here suggested that the high percentage of $A$. subterranea in the diet of vicuña is due to a higher nitrogen requirement necessary to meet the metabolic needs, which could be a result of the lower efficiency of nitrogen retention, similar to the reported by Davies et al. (2007).

As for the pseudograsses intake, both camelids consumed them in similar proportions ( $V$. vicugna: $7.2 \%$; L. guanicoe: $6.7 \%$ ). These low numbers were expected in $V$. vicugna, according to what was reported by Aguilar et al. (1995) and Borgnia et al. (2008). However, the results for L. guanicoe differ from what was reported by Puig et al. (2011) working in wetland environments, who describe a high intake of pseudograsses. Nevertheless, it is important to bear in mind that this same resource in wetlands was avoided by both camelids. This seems to be a consequence of the presence of domesticated cattle, which would cause the displacement of populations of wild camelids to feeding suboptimal habitats, similar to the reported by Borgnia et al. (2008). Since wetlands are critical habitats for wilds camelids during the stages of pregnancy and lactation, the presence of domesticated cattle can have a significant negative effect on their populations (Wurstten et al. 2014). In this sense, digestive flexibility seems to be one of the most important and widely used adjustments to changes in food quality. Thus, the hypertrophy caused by the increased food intake seems to be a response of the digestive tract, which may result in the maintenance of a constant coefficient of digestibility at increased levels of food consumption (Torres-Contreras \& Bozinovic 1997).

USE OF ZONAL AND AZONAL VEGETATION

As for the use of feeding areas, the higher contribution to both camelids diet were steppe areas species, which is explained mainly by $A$. subterranea (vicuñas) and $J$. frigida (vicuñas and guanacos) high intakes. This foraging behavior could be explained by: 1) J. frigida dominance in slopes (Osorio et al. 2011); 2) large areas covered by zonal vegetation (Osorio et al. 2011), which can be used by camelids due to its wide home range (Vicuña: 22,1 to 43,5 km², González et al. 2013; Guanaco: 65 to $163 \mathrm{~km}^{2}$, Contreras et al. 2006); and 3), the presence of domesticated animals, which have a negative effect on resource used by wild camelids (Borgnia et al. 2008; Muñoz \& Simonetti 2013). It is worth mentioning that 299 domesticated animals were registered in the study area (wetlands) (Goats: 267; horses: 32, unpublished data). In this scenario, $V$. vicugna and L. guanicoe may have shifted their plant consumption to steppe areas, which would imply processing low quality vegetation.

Despite wetland species represent less than $31 \%$ of their diet composition, they are qualitatively more important since they provide 60 and $70 \%$ of the total of consumed plant species. Therefore, the consumption and selection of wetland vegetal species seems determined by micronutrients and mineral salts content but limited by the presence of 
domestic fauna. This latter aspect is an important factor affecting the feeding of wild camelids, because they would cause the displacement of both populations of wild ungulates to feeding suboptimal habitats, reducing the use of wetlands, critical habitats, during gestation and lactation periods of wild camels (Wurstten et al. 2014). Both aspects must be evaluated to understand in detail vicuñas and guanacos foraging behavior in high Andean environments.

\section{TROPHIC INTERACTION}

Although both camelids consumed the same kind of plant species, the ecological similarity of the diets of both species was $38 \%$. This is due to the differentiating use of these resources. $V$. vicugna uses mainly shrubs and grasses species, L. guanicoe includes in its diet less proportion of shrubs, focusing mainly in grasses. The mentioned differences are also observed in trophic selection. $V$. vicugna preferred mainly shrub species $A$. subterranea and $J$. uniflora, whereas L. guanicoe preferred grasses $J$. frigida and $D$. caespitosa. The differential use of resources is also reflected in diet diversity (trophic niche breadth), which contrasts with the findings of Cajal (1989), who reported higher dietary diversity in $V$. vicugna than in L. guanicoe. The latter may result from the presence of domesticated cattle in the study area, which would have a negative effect on the trophic behavior of wild camels. This scenario should be assessed, in the future, among seasons or contrasting periods with availability of food resources.

\section{Conclusions}

In summary, we can conclude that: 1) the diet of both camelids was made up mainly by grass, and secondly by shrubs being more abundant in Vicuña than Guanaco diets; 2) A. subterranea may provide significant source of nitrogen to $V$. vicugna in zonal vegetation areas; 3 ) in a mountain environments, wetlands exploitation by wild camelids seems restricted by domestic cattle, which would cause the displacement of Vicuñas and Guanacos to suboptimal habitat for food; 4) the differential use of food resources by both camelids (trophic niche segregation) in High Andean areas may allow them to coexist in sympatry and 5) finally, these results are relevant to the management of wetlands in highlands, which are used as feeding grounds for wild and domesticated species.

\section{ACKNOWLEDGEMENTS}

The authors thank Gina Arancio and Rodomiro Osorio for their support in the field work and taxonomic determination of vegetal species, Claudio Cortés for his support in laboratory studies and Juan José Anabalón for logistic assistance. We also thank Mario Zepeda for his cooperation in samples gathering and finally, we thank the comments of anonymous readers who improved previous versions of this paper. This study was funded by Sociedad Contractual Minera El Morro, Universidad de La Serena and Universidad de Atacama.

\section{BIBLIOGRAPHY}

A.O.A.C. 1970. Official methods of analysis. Association of Official Analytical Chemist, Washington, USA.

Aguilar, M.G., Chagra Dib, E.P. \& Neuman, R. 1999. Rangeland in the diet of vicunas. En: Progress in South American Camelids Research (Eds. Gerken, M.\& C. Renieri), pp. 329-333. EAAP, Göttingen, Germany,

Aguilar, M.G., Martin, G.O., Neumann, R. \& Chagra Dib, E.P. 1995. Estimación de la composición botánica en la dieta de la vicuña (Vicugna vicugna) en la puna jujeña. Revista Argentina de Producción Animal 15:343-346.

Baied, C.A. \& Wheeler, J.C. 1993. Evolution of high Andean puna ecosystems: environment, climate, and culture change over the last 12,000 years in the central Andes. Mountain Research and Development 13(2):145-156.

Borgnia, M., VilÁ, V.L. \& CAssini, M.H. 2008. Interaction between wild camelids and livestock in an andean semidesert. Journal of Arid Environments 72:2150-2158.

Borgnia, M., VilÁ, V.L. \& Cassini, M.H. 2010. Foraging ecology of Vicuña, Vicugna vicugna, in dry Puna of Argentina. Small Ruminant Research 88(1):44-45.

CAjal, J.L. 1989. Uso de Hábitat por Vicuñas y Guanacos en la Reserva San Guillermo, Argentina. Vida Silvestre Neotropical 2:21-31.

Calenge, C. 2006. The package adehabitat for the R software: A tool for the analysis of space and habitat use by animals. Ecological Modelling 197:516-519.

Cassini, M., Arzamendia, Y., Borgnia M. \& Vilá, B. 2009. Spatial ecology and behaviour of vicuñas. En: The vicuña: The theory and practice of community based wildlife management (Ed. I.J. Gordon), pp. 35-48. Springer Verlag, Berlin, Germany.

Contreras, M., González, B. \& Novoa, F. 2006 Patrón de migración altitudinal y rango de hogar de guanacos en un ambiente andino del centro norte de Chile. En: Minería y Biodiversidad. Publicaciones (Eds. Camaño, A., Castilla, J.C. \& J.A. Simonetti), pp. 79-91. SONAMI, Chile.

Cortés, A., Miranda, E. \& LóPez-Cortés, F. 2006. Abundancia y dieta del camélido Lama guanicoe en un ambiente altoandino del norte-centro de Chile. En: Geoecología de los Andes desérticos. La Alta Montaña del Valle del Elqui (Ed. J. Cepeda), pp. 383-411. Ediciones Universidad de La Serena, La Serena, Chile.

Cortés, A., Miranda, M., Rau, J. \& Jiménez, J. 2003. Feeding habits of guanacos Lama guanicoe in the high Andes of north-central Chile. Acta Theriologica 48:229-237.

Davies, H.L., Robinson, T.F, Roeder, B.L., Sharp, M.E., Johnston, N.P., Christensen, A.C. \& Schatuje, G.B. 2007. Digestibility, nitrogen balance, and blood metabolites in llama (Lama glama) and alpaca (Lama pacos) fed barley or barley alfalfa diets. Small Ruminant Research 73:1-7.

Dizeo de Strittmatter, C.G. 1984. Clarification methods in 
vegetal materials. Parodiana 3: 169-174.

Engelhardt, W.V. \& Holler, H.P. 1982. Salivary and gastric physiology of camelids. Verhandlungen der Deutschen Zoologischen Gesellschaft 75: 185-204.

FrankLIn, W. 2011. Family Camelidae (camels). En: Handbook of the mammals of the world, Vol. 2 (Eds. Wilson, D. \& R. Mittermeier), pp. 206-247. Lynx Edicions, Barcelona, Spain.

FranKLIN, W.L. 1982. Biology, ecology, and relationship to man of the South American camelids. Special Publication Pymatuning Laboratory of Ecology 6: 457-489.

GonzÁlez, B.A, Donoso, D.S, Villalobos, R., Lagos, N. \& Iriarte A. 2013. Spatial Ecology: tracking vicuñas in the Chilean Altiplano. Argos Forum 76: 6.

Granados-Sánchez, D., Ruiz-puga, P. \& Barrera-Escorcia, H. 2008. Ecología de la herbivoría. Revista Chapingo 14 (1):51-63.

JAKSIC, F.M. \& MARone, L. 2007. Ecología de comunidades. Pontificia Universidad Católica de Chile, Santiago.

JAKsic, F.M. \& Medel, R. 1987. The Jackknife technique as a method to obtain confidence intervals and hypothesis test for ecology indexes. Medio Ambiente 8:95-103.

KNight Piésold S.A. 2008. Estudio de Impacto Ambiental Proyecto El Morro. http://seia.sea.gob.cl. Accesado: Septiembre 9, 2015.

LUCHERINI, M. 1996. Group size, spatial segregation and activity of sympatric vicuñas Vicugna vicugna and guanacos Lama guanicoe. Small Ruminant Research 20:193-198.

Lucherini, M. \& Birochio, D. 1997. Lack of aggression and avoidance between vicuña and guanaco herds grazing in the same Andean habitat. Studies on Neotropical Fauna \& Environment 32:72-75.

Manly, B.F., McDonald, L., Thomas, D., McDonald, T.L. \& ERIKSON, W. 2002. Resource Selection by Animals: Statistical Design and Analysis for Field Studies. 2nd ed. Kluwer Press, New York, USA.

MathuR, D. 1977. Food habits and competitive relationships of the bandfin shiner in Halawakee Creek, Alabama. American Midland Naturalist 97:89-100.

MénARD, M. 1984. Le règime alimentaire des vicognes (Lama vicugna) pendant une pèriode de sècheresse. Mammalia 48:529-539.

Mueller-Dombois, D. \& Ellemberg, H. 1974. Aims and Methods of Vegetation Ecology. John Wiley and Sons, New York, USA.

Muñoz, A.E. \& Simonetti, J.A. 2013. Diet of guanaco in sheepfree rangeland in Tierra del Fuego, Chile. Ciencia e Investigación Agraria 40(1):185-191.

Osorio, R., Cortés, A., Tirado, C. \& López, D. 2011. Flora y Vegetación del Área Mina-Planta: Formaciones Vegetales y Productividad. Informe técnico. Proyecto Minero El Morro.

Puig, S., Rosi, M.I., Videla, F. \& Méndez, E. 2011. Summer and winter diet of the guanaco and food availability for a High Andean migratory population (Mendoza, Argentina). Mammalian Biology 76:727-734.

R Development Core Team. 2008. R: A language and environment for statistical computing. R Foundation for Statistical Computing, Vienna, Austria. ISBN 3-900051-07-0, URL: http://www.R-project.org.

SAG. 2012. La Ley de caza y su reglamento. Departamento de Protección de los Recursos Naturales Renovables. Ley de Caza No 19.473 del Ministerio de Agricultura, Servicio Agrícola y Ganadero.

SAN Martin, F. 1987. Comparative forage selectivity and nutrition of South American camelids and sheep. Ph.D. Diss., Texas Tech University, Lubbock.

Schoener, T.W. 1968. The Anolis lizards of Bimini: Resource partitioning in a complex fauna. Ecology 51:408-418.

Shannon, C.E. 1948. A mathematical theory of communication. Bell System Technical Journal 27:379-423.

Sponheimer, M., Robinson, T. \& Roeder, B. 2003. Digestion and passage rates of grass hays by llamas, alpacas, goats, rabbits and horses. Small Ruminant Research 48:149-154.

Squeo, F., Warner, B.G., Aravena, R. \& Espinoza, D. 2006a. Bofedales: high altitude peatlands of the central Andes. Revista Chilena de Historia Natural 79:245-255.

Squeo, F.A., Cepeda., J, Olivares, N. \& Arroyo, M.T.K. $2006 \mathrm{~b}$. Interacciones ecológicas en la alta montaña del Valle del Elqui. En: Geoecología de los Andes Desérticos: La Alta Montaña del Valle del Elqui (Ed. J. Cepeda), pp. 69-103. Ediciones Universidad de La Serena, La Serena, Chile.

Tirado, C., Cortés, A., Miranda-Urbina, E. \& Carretero, M.A. 2012. Trophic preferences in an assemblage of mammal herbivores from Andean Puna (Northern Chile). Journal of Arid Environments 79: 8-12.

Torres-Contreras, H. \& Bozinovic, F. 1997. Foraging strategy in an herbivorous small mammal in central Chile: time minimizer or energy maximizer? Revista Chilena de Historia Natural 70:577-585.

Villagrán, C., Arroyo, M.T.K. \& Marticorena, C. 1983. Efectos de la desertización en la distribución de la flora andina de Chile. Revista Chilena de Historia Natural 56:137-157.

Williams, O. 1962. A technique for studying microtine food habits. Journal of Mammalogy 43:365-368.

Wurstten, A., Novaro, A.J. \& Walker, S. 2014. Habitat use and preference by guanacos, vicuñas, and livestock in an altitudinal gradient in northwest Argentina. European Journal Wildlife Research 60:35-43. 